\author{
자돈 및 비육돈에 있어 옥수수의 가공 효과 \\ 한영근* · 김인호** . 홍종욱*** · 권오석** . 민병준** . 이원백** . 손경승** . 이지훈**** \\ 농협중앙회 축산연구소*, 단국대학교 동물자원과학과**, \\ (주)대상사료***, (주)이지바이오시스템****
}

\title{
Effects of Extruded Corn in Nursery and Finishing Pigs
}

\author{
Y. K. Han*, I. H. Kim**, J. W. Hong***, O. S. Kwon**, B. J. Min**, \\ W. B. Lee**, K. S. Shon** and J. H. Lee****
}

Livestock Research Institute, National Agricultural Cooperatives Federation, 456-824, Korea*, Department of Animal Resource \& Sciences, Dankook University, Cheonan, 330-714, Korea**,

DAESANG FEED CO., LTD., Anseong, 456-843, Korea***,

Easy Bio System, Inc., Seoul, 135-937, Korea****

\begin{abstract}
For the Exp. 1, a total of sixty pigs(15.95 $\pm 0.09 \mathrm{~kg}$ average initial body weight) were used in a 28-d growth assay to determine the effects of extruded chinese corn on growth performance and nutrient digestibility in nursery pigs. Dietary treatments included 1) UCORN(U.S. corn-SBM based diet), 2) CCORN(Chinese corn-SBM based diet) and 3) ECCORN(Extruded Chinese corn-SBM based diet). Overall period, average daily gain of pigs fed ECCORN diet was higher than that of pigs fed CCORN diet(547 vs $522 \mathrm{~g} / \mathrm{d}$ ), however, there was not significant difference. On day 10 of the experiment, pigs fed UCORN and ECCORN diet had significantly increased in DM and DE digestibilities compared to pigs fed CCORN $\operatorname{diet}(\mathrm{I}<0.05)$. Also, on day 24 of the experiment, pigs fed UCORN and ECCORN diet had a significant increase in DM digestibility compared to pigs fed CCORN $\operatorname{diet}(\mathrm{I}<0.05)$. Pigs fed ECCORN diet had significantly increased DE digestibility compared to pigs fed CCORN $\operatorname{diet}(\mathrm{I}<0.05)$. For the Exp. 2, three cannulated barrows $(54.09 \mathrm{~kg}$ average initial body weight) were used to determine the apparent ileal digestibilities of amino acids and nutrient digestibility of extruded corn in finishing pigs. Dietary treatments were the same as in Exp. 1. Apparent ileal digestibility of cystine was greater for UCORN and ECCORN than for CCORN(I $<0.05)$. Apparent digestibility of DM at the total tract was greater for UCORN and ECCORN than for CCORN(I < 0.05). Pigs fed UCORN and ECCORN diet had a significant increase in apparent total tract digestibility of $\mathrm{N}$ compared to pigs fed CCORN $\operatorname{diet}(\mathrm{I}<0.05)$. In conclusion, the results obtained from these feeding trials suggest that the extruded corn for nursery pigs had affected growth performance and DM and DE digestibilities. In finishing pigs, extruded corn was an effective means to improve apparent total tract digestibilities of DM and $\mathrm{N}$.
\end{abstract}

(Key words : Corn, Extrusion, Availability, Pigs)

$$
\mathrm{I} \text { 서 론 }
$$

양돈사료내 에너지 공급원으로 가장 많이 사 용되고 있는 옥수수는 사료용 곡물 중에서 가
장 많이 사용되는 원료 중 하나이다. 옥수수는 대사에너지와 정미에너지 함량이 높으며, 조섬 유 함량이 낮은 에너지 공급원 원료이다. 그러 나 단백질 함량이 낮고 필수아미노산 중 라이

Corresponding author : I. H. Kim, Dept. Animal Resource \& Sciences, Dankook University, Cheonan, 330-714, Korea, Tel : +82-41-550-3652, Fax : +82-41-553-1618, E-mail : inhokim@dankook.ac.kr 
신과 트립토판의 함량이 낮기 때문에(NRC, 1998) 옥수수 위주의 사료에 합성아미노산의 첨가가 고려되어야 한다. 지난 5년 동안 전세 계 옥수수 생산량은 500-600 mmt 였으며, 이 중 미국에서 생산된 옥수수가 $40 \%$ 이상을 차 지하였다(U.S. Grains Council, 2001). 또한, 2002/2003년 전세계 옥수수 수출량 중 미국이 차지하는 비중은 $66 \%$ 였다(U.S. Grains Council, 2002). 중국은 세계 옥수수 생산량 2위를 차지 하는 국가로서, 지난 7년 동안 계속적인 증가 세를 유지해 왔으며, 2002/2003년 중국 옥수수 생산량은 $125 \mathrm{mmt}$ 였으며, 수출량은 $10 \mathrm{mmt}$ 으 로 세계 옥수수 수출량의 $13 \%$ 를 차지했다(U.S. Grains Council, 2002).

그러나 북미지역과 호주지역의 가뭄과 고온 현상으로 미국의 옥수수 선물시세가 큰폭으로 상승하고 있으며, 사료용 옥수수의 대부분을 수입하는 국내의 현실을 감안하여 볼 때, 이러 한 국제시세 상승은 옥수수 대체원료의 사용 혹은 가격이 상대적으로 낮은 옥수수의 사용이 현실적으로 고려되고 있다. 국내에서는 옥수수 가 미산, 남미산, 중국산 등이 수입되어 사료용 으로 사용되고 있으나, 미산 옥수수의 가격 상 승으로 중국산 옥수수가 수입되어 양돈사료원 료로 사용되고 있다. 그러나 중국산 옥수수는 선적시 품질 평가가 미비한 편이며, 가축의 이 용성 평가가 아직까지 확립되어 있지 않다. 따 라서 중국산 옥수수 사용에 따른 가축의 성장 율 감소와 이에 따른 생산비 증가 가능성이 제 기되고 있다.

본 연구의 목적은 자돈 및 비육돈에 있어 중 국산 옥수수의 이용성을 평가하고 중국산 옥수 수의 이용성을 높이기 위하여 익스트루젼 가공 하여 성장 및 영양소 이용성에 미치는 영향을 평가하기 위하여 실시하였다.

\section{프재료 및 방법}

\section{1. 시험 1}

(1) 시험동물 및 시험설계

개시시 체중 $15.95 \pm 0.09 \mathrm{~kg}$ 의 3 원 교잡종
[(Duroc $\times$ Yorkshire $) \times$ Landrace] 자돈 60두를 공시하여 28 일간 사양시험을 실시하였다. 시험 설계는 미산 옥수수 - 대두박 위주로 시험사료 를 배합한 처리구(UCORN), 중국산 옥수수-대 두박 위주로 시험사료를 배합한 처리구(CCORN) 그리고 익스트루젼 가공한 중국산 옥수수 - 대두 박 위주로 시험사료를 배합한 처리구(ECCORN) 로 3 개 처리로 하여 처리당 5반복, 반복당 4마 리씩 완전임의 배치하였다.

중국산 옥수수의 익스트루젼 가공은 습식 익 스트루더(Matador $\left.{ }^{\circledR}\right)$ 를 이용하여 $130 \pm 2{ }^{\circ} \mathrm{C}$. 익 스트루젼하였다. 익스트루젼 가공 후, 햄머밀을 이용하여 분쇄한 후 시험사료 배합에 사용하였 다.

\section{(2) 시험사료 및 사양관리}

기초사료는 $3,340 \mathrm{kcal}$ 대사에너지 $/ \mathrm{kg}, 20.80 \%$ 조단백질, $1.20 \%$ 라이신, $0.70 \%$ 칼슘, $0.60 \%$ 인 을 함유토록 하였다(Table 1). 시험사료는 가루 형태로 자유채식토록 하였으며, 물은 자동급수 기를 이용하여 자유로이 먹을 수 있도록 하였 다. 체중 및 사료섭취량은 사양시험 개시시, 14 일째 되는 날 그리고 시험종료시에 측정하여 일당증체량, 일당사료섭취량, 사료효율을 계산 하였다.

영양소 소화율을 측정하기 위하여 표시물로 서 산화크롬 $\left(\mathrm{Cr}_{2} \mathrm{O}_{3}\right)$ 을 사료내 $0.2 \%$ 첨가하였으 며, 시험개시 후 10 일과 24 일째 되는 날에 동 일한 시간동안 배설된 분을 채취하여 건조시킨 후 분석에 이용하였다.

\section{(3) 화학분석 및 통계처리}

사료와 분내 건물과 질소 함량은 $\mathrm{AOAC}$ (1995) 방법에 의해 분석하였으며, 총에너지 함 량은 Adiabatic Bomb Calorimeter(Model 1241, Parr Instrument Co., USA)에 의해서 측정하였 다. $\mathrm{Cr}$ 농도는 UV absorption spectrophotometry (Shimadzu, UV-1201-Japan)에 의해서 결정되었 다.

모든 자료는 SAS(1996)의 GLM procedure를 이용 Duncan's multiple range test(Duncan, 1955) 로 처리하여 평균간의 유의성을 검정하였다. 
Table 1. Diet composition for Exp. 1(as-fed basis)

\begin{tabular}{lr}
\hline Ingredients & $\%$ \\
\hline \hline Corn grain & 54.50 \\
Soybean meal & 36.30 \\
Wheat bran & 0.35 \\
PITALAC 21/22 ${ }^{1)}$ & 6.40 \\
Salt & 0.25 \\
Tricalcium phosphate & 1.00 \\
Limestone & 0.30 \\
Choline chloride & 0.20 \\
Vitamin premix ${ }^{2)}$ & 0.20 \\
Trace mineral premix ${ }^{3)}$ & 0.20 \\
Chlortetracycline & 0.10 \\
Chromium oxide ${ }^{4)}$ & 0.20 \\
\hline Chemical composition ${ }^{5)}$ & \\
ME, kcal/kg & 3340 \\
Crude protein, \% & 20.80 \\
Lysine, \% & 1.20 \\
Methionine, \% & 0.32 \\
Calcium, \% & 0.70 \\
Phosphorus, \% & 0.60 \\
\hline ( $\%$
\end{tabular}

${ }^{1)}$ Homogenized coconut oil, lactose, trace mineral and lactic acid.

${ }^{2)}$ Provided per kg diet : 20,000IU of vitamin A; $4,000 \mathrm{IU}$ of vitamin $\mathrm{D}_{3} ; 80 \mathrm{IU}$ of vitamin $\mathrm{E} ; 16 \mathrm{mg}$ of vitamin $\mathrm{K}_{3}$; $4 \mathrm{mg}$ of thiamine; $20 \mathrm{mg}$ of riboflavin; $6 \mathrm{mg}$ of pyridoxine; $0.08 \mathrm{mg}$ of vitamin $\mathrm{B}_{12} ; 120 \mathrm{mg}$ of niacin; 50mg of Ca-pantothenate; $2 \mathrm{mg}$ of folic acid and $0.08 \mathrm{mg}$ of biotin.

${ }^{3)}$ Provided per kg diet:140mg of $\mathrm{Cu}$; $179 \mathrm{mg}$ of $\mathrm{Zn}$; $12.5 \mathrm{mg}$ of $\mathrm{Mn} ; 0.5 \mathrm{mg}$ of $\mathrm{I} ; 0.25 \mathrm{mg}$ of Co and $0.4 \mathrm{mg}$ of Se.

4) Used as an indigestible marker.

${ }^{5)}$ Calculated value.

\section{2. 시험 2}

(1) 외과적 수술 및 T-cannulas 설치

회장과 맹장 인접부에서 상단부위로 대략 15 $\mathrm{cm}$ 되는 위치에 T-cannulas를 외과적 수술기법
을 이용하여 설치하였다. 외과적 수술시 사용

한 마취제는 Stresnil ${ }^{\mathrm{TM}}$ (Janssen Pharmaceutica, Belgium)과 유한 Ketamine 50 Injection(주식회 사 유한, Korea)을 이용하여 실시하였다. 외과 적 수술을 실시한 후, 거세돈은 대사 케이지 에 옮겨졌다. 외과적 수술 후, 회복기간은 14 일 이었으며, 대사시험이 실시되는 대사시험 실의 온도는 $22^{\circ} \mathrm{C}$ - 유지될 수 있도록 조절 하였다.

(2) 시험동물 및 시험설계

개시시 체중 $54.09 \mathrm{~kg}$ 의 3원 교잡종[(Duroc $\times$ Yorkshire) $\times$ Landrace] 거세돈 3 두를 공시하여 대사시험을 실시하였다. 시험설계는 $3 \times 3$ latin squire로 실시하였으며, 4일간 시험사료를 급여 한 후 2일간 분을 채취하고 2일간(12시간/일) 회장소화물을 채취하였다.

처리구는 미산 옥수수 - 카제인 - 대두박 위주 로 시험사료를 배합한 처리구(UCORN), 중국산 옥수수 - 카제인 - 대두박 위주로 시험사료를 배 합한 처리구(CCORN) 그리고 익스트루젼 가공 한 중국산 옥수수 - 카제인 - 대두박 위주로 시 험사료를 배합한 처리구(ECCORN) 3개 처리로 하였다.

중국산 옥수수의 익스트루젼 가공 조건은 시 험 1 과 같다.

\section{(3) 시험사료 및 사료급여}

기초사료는 $3,340 \mathrm{kcal}$ 대사에너지 $/ \mathrm{kg}, 16.00 \%$ 조단백질, $0.85 \%$ 라이신, $0.60 \%$ 칼슘, $0.50 \%$ 인을 함유토록 하였다(Table 2). 일일사료급여 량은 Armstrong과 Mitchell(1955)이 제시한 방 법에 따라 $0.05 \times \mathrm{BW}^{0.9}$ 방정식에 따라 산출 된 값으로 하였으며, 산출된 사료급여량을 12 시간 간격으로 1일 2회(08:00시와 20:00시) 급 여하였다.

(4) 화학분석 및 통계처리

사료, 분 및 회장소화물내 건물과 질소 함량 은 AOAC(1995) 방법에 의해 분석하였으며, $\mathrm{Cr}$ 농도는 UV absorption spectrophotometry(Shimadzu, UV-1201-Japan)에 의해서 결정되었다. 외관 
Table 2. Diet composition for Exp. 2(as-fed basis)

\begin{tabular}{lr}
\hline Ingredients & $\%$ \\
\hline \hline Corn grain & 83.32 \\
Casein & 8.77 \\
Soybean meal & 2.80 \\
Cellulose & 2.41 \\
Limestone & 1.00 \\
Dicalcium phosphate & 0.79 \\
Salt & 0.20 \\
Vitamin premix ${ }^{1)}$ & 0.18 \\
Trace mineral premix ${ }^{2)}$ & 0.13 \\
Antibiotic & 0.10 \\
DL-methionine & 0.09 \\
L-lysine $\cdot$ Cl & 0.01 \\
Chromium oxide ${ }^{4)}$ & 0.20 \\
\hline Chemical composition ${ }^{5)}$ & \\
ME, kcal/kg & 0.5340 \\
Crude protein, \% & 16.00 \\
Lysine, \% & 0.85 \\
Methionine, \% & 0.24 \\
Calcium, \% & 0.60 \\
Phosphorus, \% & 0.50 \\
\hline Povide & 2000 \\
\hline
\end{tabular}

${ }^{1)}$ Provided per kg diet : 10,000 IU of vitamin A, 2,000 IU of vitamin $\mathrm{D}_{3}, 42 \mathrm{IU}$ of vitamin $\mathrm{E}, 5 \mathrm{mg}$ of vitamin $\mathrm{K}$, $9.6 \mathrm{mg}$ of vitamin $\mathrm{B}_{2}, 2.45 \mathrm{mg}$ of vitamin $\mathrm{B}_{6}, 40$ $\mu \mathrm{g}$ of vitamin $\mathrm{B}_{12}, 27 \mathrm{mg}$ of pantothenic acid, $49 \mathrm{mg}$ of niacin and $0.05 \mathrm{mg}$ of biotin.

${ }^{2)}$ Provided per $\mathrm{kg}$ diet : $140 \mathrm{mg}$ of $\mathrm{Cu}, 145 \mathrm{mg}$ of $\mathrm{Fe}$, $179 \mathrm{mg}$ of $\mathrm{Zn}, 12.5 \mathrm{mg}$ of $\mathrm{Mn}, 0.5 \mathrm{mg}$ of I, 0.25 $\mathrm{mg}$ of Co and $0.4 \mathrm{mg}$ of Se.

${ }^{3)}$ Provided by $50 \mathrm{mg}$ carbadox per kg of complete diet.

4) Used as an indigestible marker.

${ }^{5)}$ Calculated value.

상 아미노산 회장소화율을 측정하기 위하여 사 료와 회장소화물내 아미노산 함량은 24시간동안 $110^{\circ} \mathrm{C}$ 서 $6 \mathrm{~N} \mathrm{HCl}$ 로 가수분해한 후, 아미노산 분석기(Biochrom 20, Pharmacia Biotech, England) 를 이용하여 분석하였다.
모든 자료는 SAS(1996)의 GLM procedure를 이용 Duncan's multiple range test(Duncan, 1955) 로 처리하여 평균간의 유의성을 검정하였다.

\section{III 결 과}

\section{1. 시험 1}

자돈에 있어 중국산 옥수수의 익스트루젼 가 공이 성장능력에 미치는 영향을 Table 3에 나 타내었다. 0 4일까지의 사양시험 기간동안, 일 당증체량에 있어서 ECCORN 처리구가 CCORN 처리구보다 6\%(505 vs $476 \mathrm{~g} / \mathrm{d})$ 더 높은 것으로 나타났으나 유의적인 차이는 보이지 않았다. 일당사료섭취량 및 사료효율에 있어서도 처리 구간에 유의적인 차이를 보이지 않았다. 14 28 일까지의 사양시험 기간동안, 일당증체량에 있어서는 ECCORN 처리구가 CCORN 처리구보 다 4\%(589 vs $568 \mathrm{~g} / \mathrm{d})$ 더 높은 것으로 나타났 으나 유의적인 차이를 보이지 않았으며, 일당 사료섭취량 및 사료효율에 있어서도 처리구간 에 유의적인 차이를 보이지 않았다. 전체 사양 시험 기간동안, 일당증체량에 있어서는 미산 옥수수를 급여한 처리구가 가장 높았으며, 중 국산 옥수수를 익스트루젼 가공하면 성장율이 높아졌으나(547 vs 522 g/d), 표준오차가 컸기 때문에 유의적인 차이는 보이지 않았다. 사료 효율에 있어서도 ECCORN 처리구가 CCORN 처리구보다 높았으나(0.53 vs 0.47) 유의적인 차 이는 보이지 않았다.

자돈에 있어 중국산 옥수수의 익스트루젼 가 공이 영양소 소화율에 미치는 영향을 Table 4 에 나타내었다. 사양시험 개시후 10 일째 되는 날에 채취한 분을 이용하여 분석한 건물과 가 소화 에너지 소화율에 있어서는 UCORN 처리 구와 ECCORN 처리구가 CCORN 처리구보다 유의적으로 높은 것으로 평가되었다( $<<0.05)$. 또한, 사양시험 개시후 24 일째 되는 날에 채취 한 분을 이용하여 분석한 건물 소화율에 있어 서도 $\mathrm{UCORN}$ 처리구과 $\mathrm{ECCORN}$ 처리구가 CCORN 처리구보다 유의적으로 높은 것으로 평가되었으며( $<0.05)$, 가소화 에너지 소화율 
Table 3. Effects of extruded corn on growth performance in nursery pigs(Exp. 1) ${ }^{1)}$

\begin{tabular}{lcccc}
\hline Item & UCORN $^{2)}$ & CCORN $^{2)}$ & ECCORN $^{2)}$ & SE $^{3)}$ \\
\hline \hline 0-14 days & & & & \\
Average daily gain, g & 513 & 476 & 505 & 30 \\
Average daily feed intake, g & 914 & 945 & 941 & 59 \\
Gain/feed & 0.56 & 0.50 & 0.54 & 0.03 \\
\hline 14-28 days & & & & \\
Average daily gain, g & 608 & 568 & 589 & 34 \\
Average daily feed intake, g & 1140 & 1275 & 1140 & 127 \\
Gain/feed & 0.53 & 0.45 & 0.52 & 0.04 \\
\hline 0-28 days & & & & \\
Average daily gain, g & 561 & 522 & 547 & 25 \\
Average daily feed intake, g & 1027 & 1110 & 1041 & 87 \\
Gain/feed & 0.55 & 0.47 & 0.53 & 0.03 \\
\hline
\end{tabular}

${ }^{1)}$ Sixty pigs with an average initial body weight of $15.95 \pm 0.09 \mathrm{~kg}$.

2) Abbreviated UCORN, U.S. corn ; CCORN, Chinese corn; ECCORN, Extruded Chinese corn.

${ }^{3)}$ Standard error.

Table 4. Effects of extruded corn on nutrient digestibility in nursery pigs (Exp. 1)

\begin{tabular}{|c|c|c|c|c|}
\hline Item, \% & $\mathrm{UCORN}^{2)}$ & $\mathrm{CCORN}^{2)}$ & ECCORN $^{2)}$ & $\mathrm{SE}^{3)}$ \\
\hline \multicolumn{5}{|l|}{10 days } \\
\hline DM & $77.10^{\mathrm{a}}$ & $71.82^{\mathrm{C}}$ & $75.21^{\mathrm{b}}$ & 0.57 \\
\hline $\mathrm{N}$ & 77.30 & 75.53 & 76.52 & 0.94 \\
\hline $\mathrm{DE}$ & $78.65^{\mathrm{a}}$ & $71.48^{\mathrm{C}}$ & $76.65^{b}$ & 0.58 \\
\hline \multicolumn{5}{|l|}{24 days } \\
\hline DM & $81.05^{\mathrm{a}}$ & $78.98^{\mathrm{b}}$ & $80.62^{\mathrm{a}}$ & 0.43 \\
\hline $\mathrm{N}$ & $83.21^{\mathrm{a}}$ & $79.64^{b}$ & $81.46^{\mathrm{ab}}$ & 0.60 \\
\hline DE & $84.98^{\mathrm{a}}$ & $79.07^{c}$ & $82.05^{\mathrm{b}}$ & 0.40 \\
\hline
\end{tabular}

${ }^{1)}$ Sixty pigs with an average initial body weight of $15.95 \pm 0.09 \mathrm{~kg}$.

2) Abbreviated UCORN, U.S. corn ; CCORN, Chinese corn; ECCORN, Extruded Chinese corn.

3) Standard error.

${ }^{\mathrm{abc}}$ Means in the same row with different superscripts $\operatorname{differ}(\mathrm{I}<0.05)$.

에 있어서는 UCORN 처리구가 다른 처리구와 비교하여 가장 높았으며(I<0.05), ECCORN 처 리구가 CCORN 처리구보다 유의적으로 높게 평가되었다( $\mathrm{H}<0.05)$.

\section{2. 시험 2}

비육돈에 있어 중국산 옥수수의 익스트루젼 가공이 외관상 아미노산 소화율에 미치는 영향 을 Table 5에 나타내었다. 라이신 소화율에 있어 서는 UCORN와 비교하여 CCORN과 ECCORN
처리구가 더 높은 것으로 평가되었으나, 표준 오차가 크기 때문에 유의적인 차이는 보이지 않았다. 황함유 아미노산인 메치오닌의 외관상 아미노산 소화율에 있어서는 처리구간에 유의 적인 차이는 보이지 않았으나, 시스틴의 외관 상 아미노산 소화율에 있어서는 UCORN과 $\mathrm{EECORN}$ 처리구가 CCORN 처리구와 비교하여 유의적으로 높게 평가되었다 $(\mathrm{I}<0.05)$.

비육돈에 있어 중국산 옥수수의 익스트루젼 가공이 건물 및 질소의 분과 회장 소화율에 미 치는 영향을 Table 6에 나타내었다. 건물 소화 
Table 5. Effects of extruded corn on apparent amino acids digestibility in finishing pigs (Exp. 2) ${ }^{1)}$

\begin{tabular}{|c|c|c|c|c|}
\hline Item, \% & $\mathrm{UCORN}^{2)}$ & $\mathrm{CCORN}^{2)}$ & ECCORN $^{2)}$ & $\mathrm{SE}^{3)}$ \\
\hline \multicolumn{5}{|c|}{ Essential amino acids } \\
\hline Arginine & 92.12 & 90.01 & 91.60 & 0.68 \\
\hline Histidine & 89.67 & 88.09 & 90.43 & 0.71 \\
\hline Isoleucine & 89.22 & 87.45 & 88.81 & 0.89 \\
\hline Leucine & 91.83 & 91.25 & 90.60 & 0.71 \\
\hline Lysine & 90.62 & 92.15 & 92.81 & 1.17 \\
\hline Methionine & 95.33 & 95.01 & 93.98 & 0.52 \\
\hline Phenylalanine & 90.99 & 89.63 & 90.00 & 0.89 \\
\hline Threonine & 82.63 & 79.01 & 83.25 & 1.41 \\
\hline Valine & 88.69 & 86.64 & 88.15 & 0.98 \\
\hline \multicolumn{5}{|c|}{ Non-essential amino acids } \\
\hline Alanine & 84.82 & 83.96 & 82.75 & 1.26 \\
\hline Asparatic acid & 86.54 & 83.79 & 85.90 & 1.10 \\
\hline Cystine & $71.30^{\mathrm{a}}$ & $64.10^{\mathrm{b}}$ & $73.39^{\mathrm{a}}$ & 2.82 \\
\hline Glutamic acid & 91.95 & 91.49 & 90.66 & 0.69 \\
\hline Glycine & $65.46^{\mathrm{a}}$ & $64.82^{\mathrm{a}}$ & $63.39^{\mathrm{b}}$ & 0.65 \\
\hline Proline & 92.40 & 91.02 & 91.37 & 0.68 \\
\hline Serine & 87.55 & 85.43 & 88.04 & 1.02 \\
\hline Tyrosine & 91.09 & 90.19 & 90.80 & 0.77 \\
\hline
\end{tabular}

1) Three barrows with an average initial body weight of $54.09 \mathrm{~kg}$.

2) Abbreviated UCORN, U.S. corn ; CCORN, Chinese corn; ECCORN, Extruded Chinese corn.

3) Standard error.

${ }^{\text {ab }}$ Means in the same row with different superscripts differ $(I<0.05)$.

Table 6. Effects of extruded corn on DM and $\mathrm{N}$ digestibility in finishing pigs (Exp. 2) ${ }^{1)}$

\begin{tabular}{lcccc}
\hline Item, \% & UCORN $^{2)}$ & CCORN $^{2)}$ & ECCORN $^{2)}$ & SE $^{3)}$ \\
\hline \hline DM digestibility & & & & \\
Small intestine & 80.52 & 75.74 & 80.02 & 1.86 \\
Total tract & $87.73^{\mathrm{a}}$ & $85.23^{\mathrm{b}}$ & $87.58^{\mathrm{a}}$ & 0.40 \\
Difference & 7.21 & 9.49 & 7.56 & 2.17 \\
\hline N digestibility & & & & \\
Small intestine & 87.15 & 81.08 & 84.48 & 2.03 \\
Total tract & $92.56^{\mathrm{a}}$ & $87.39^{\mathrm{b}}$ & $92.68^{\mathrm{a}}$ & 0.43 \\
Difference & 5.41 & 6.31 & 8.20 & 2.28 \\
\hline
\end{tabular}

${ }^{1)}$ Three barrows with an average initial body weight of $54.09 \mathrm{~kg}$.

${ }^{2)}$ Abbreviated UCORN, U.S. corn ; CCORN, Chinese corn; ECCORN, Extruded Chinese corn.

${ }^{3)}$ Standard error.

${ }^{\mathrm{ab}}$ Means in the same row with different superscripts $\operatorname{differ}(\mathrm{I}<0.05)$.

율에 있어서는 UCORN과 ECCORN 처리구가 로 나타났다(I<0.05).

CCORN 처리구보다 분 소화율이 유의적으로 높은 것으로 나타났다(I<0.05). 질소 소화율에 있어서도 UCORN과 ECCORN 처리구가 CCORN

처리구보다 분 소화율이 유의적으로 높은 것으 익스트루젼 가공한 옥수수를 이용한 사양시

$\mathrm{IV}$ 고 찰 
험이 여러 연구자들에 의해서 실시되었다. HerkeIman 등(1990)은 육성돈에 있어 영양소 소화율 에 대한 옥수수의 익스트루젼 효과를 평가하기 위하여 회장소화율 측정 시험을 실시하였다. 시험 결과를 보면, 분쇄한 옥수수를 급여한 처 리구보다 익스트루젼 가공한 옥수수를 급여한 처리구의 분내 외관상 가소화 에너지(85.64 vs 87.70\%) 및 대사 에너지(83.68 vs $85.63 \%)$ 소화 율이 유의적으로 증가하였다고 보고하였다. 이 러한 결과는 본 사양시험의 결과와 일치하는 것으로, 시험 1 의 결과에서 볼 수 있듯이 중국 산 옥수수를 익스트루젼 가공 처리하면 외관상 가소화 에너지 소화율이 4 \% 향상되는 것으 로 나타났다. 그러나 Herkelman 등(1990)은 질 소 이용율에는 차이를 보이지 않아 옥수수의 익스트루젼 가공 처리는 에너지 이용율에는 영 향을 미치는 것으로 보고하여, 본 시험의 결과 와 상이한 결과를 나타내었다. Serrano(1997)은 분쇄한 옥수수와 익스트루젼 가공한 옥수수의 전분호화도가 각각 22.87 과 $89.10 \%$ 인 옥수수를 이유자돈에 급여한 사양시험에서, 1 단계 사료 를 급여하는 기간동안 이유자돈의 일당증체량 은 분쇄한 옥수수를 급여한 처리구보다 익스트 루젼 가공한 옥수수를 급여한 처리구가 높은 성장율(93 vs $107 \mathrm{~g})$ 을 보였으며, 일당사료섭취 량도 익스트루젼 가공한 옥수수가 $12 \%$ 더 높 았다. 이러한 결과는 2 주령된 자돈은 pancreatic amylase와 disaccharidases가 충분히 분비 되지 못하기 때문에 성장율이 떨어지는 것으로 (Sewell과 Maxwell, 1966) 2 주령된 자돈사료 에 효소제를 첨가하여 주거나 혹은 열처리를 통한 사료의 이용성을 높일 수 있다. 이러한 연구 결과들은 본 사양시험 1 과 2 의 결과에서 볼 수 있는 것으로, 자돈시기에서는 옥수수의 익스트루젼 가공이 성장율이나 건물과 가소화 에너지 소화율에 영향을 미치는 것으로 판단되 나, 비육돈 시기에서는 크게 영향을 미치지 못 하는 것으로 사료된다. 또한, Hongtrakul 등 (1998)은 이유자돈에 있어 옥수수의 익스트루젼 가공이 성장에 미치는 영향을 평가하였다. 전 분호화도가 $14.5,38.7,52.7,64.4$ 그리고 $89.3 \%$ 인 옥수수를 이유자돈에 급여한 결과, 영양소 소화율에 있어서는 전분호화도가 38 $1 \%$ 인
옥수수가 이유자돈에게는 적절한 것으로 보고 하였다.

미산 옥수수의 국제 가격 상승으로 중국산 옥수수를 사용해야만 하는 시점에서 중국산 옥 수수에 대한 돼지의 이용성 평가는 중요한 문 제다. 본 사양시험의 결과를 보면, 자돈시기에 중국산 옥수수를 익스트루젼 가공하여 급여하 면, 성장율이 향상되고, 분내 건물과 가소화 에 너지 소화율이 증가하는 것으로 나타났다. 그 러나, 비육돈 시기에 중국산 옥수수의 익스트 루젼 가공효과는 나타나지 않았다. 따라서 중 국산 옥수수의 익스트루젼 가공은 비육돈 시기 보다는 자돈시기에 더욱 효과적이며, 추가적으 로 자돈시기에서 중국산 옥수수에 대한 다양한 가공 방법을 통한 가장 효과적인 가공 방법을 확립해야 할 것으로 사료된다.

$$
\mathrm{V} \text { 요 약 }
$$

시험 1 은 자돈에 있어 중국산 옥수수의 이용 성을 높이기 위하여 중국산 옥수수를 익스트루 젼 가공하였을 때 성장 및 영양소 소화율에 미 치는 영향을 평가하기 위하여 실시하였다. 개 시시 체중 $15.95 \pm 0.09 \mathrm{~kg}$ 의 3원 교잡종 자돈 60 두를 공시하여 28일간 사양시험을 실시하였다. 시험설계는 미산 옥수수 - 대두박 위주로 시험사 료를 배합한 처리구(UCORN), 중국산 옥수수대두박 위주로 시험사료를 배합한 처리구 $(\mathrm{CCORN})$ 그리고 익스트루젼 가공한 중국산 옥 수수 - 대두박 위주로 시험사료를 배합한 처리 구 $(\mathrm{ECCORN})$ 로 3 개 처리로 하였다. 전체 사양 시험 기간동안, 일당증체량에 있어서는 ECCORN 처리구가 CCORN 처리구보다 더 높았으나 (547 vs $522 \mathrm{~g} / \mathrm{d}$ ) 유의적인 차이는 보이지 않았 다. 사양시험 개시후 10 일째 되는 날에 채취한 분을 이용하여 분석한 건물과 가소화 에너지 소화율에 있어서는 UCORN 처리구와 ECCORN 처리구가 CCORN 처리구보다 유의적으로 높은 것으로 평가되었다 $(\mathrm{I}<0.05)$. 또한, 사양시험 개 시후 24일째 되는 날에 채취한 분을 이용하여 분석한 건물 소화율에 있어서는 UCORN 처리 구와 ECCORN 처리구가 CCORN 처리구보다 유의적으로 높은 것으로 평가되었으며(I $<0.05)$, 
가소화 에너지 소화율에 있어서는 UCORN 처 리구가 다른 처리구와 비교하여 가장 높았다 ( $<0.05)$. 또한, $\mathrm{CCORN}$ 처리구와 비교하여 ECCORN 처리구가 유의적으로 높게 평가되었 다( $<0.05)$. 시험 2 는 비육돈에 있어 중국산 옥수수를 익스트루젼 가공이 외관상 아미노산 및 영양소 소화율에 미치는 영향을 평가하기 위하여 실시하였다. 개시시 체중 $54.09 \mathrm{~kg}$ 의 3원 교잡종 거세돈 3 두를 공시하여 대사시험을 실 시하였으며, 처리구는 시험 1 과 동일하였다. 시 스틴의 외관상 아미노산 소화율에 있어서는 $\mathrm{UCORN}$ 과 EECORN 처리구가 CCORN 처리구 와 비교하여 유의적으로 높게 평가되었다(I< 0.05). 건물 소화율에 있어서는 UCORN과 ECCORN 처리구가 CCORN 처리구보다 분 소 화율이 유의적으로 높은 것으로 나타났다( 0.05). 또한, 질소 소화율에 있어서도 UCORN과 $\mathrm{ECCORN}$ 처리구가 CCORN 처리구보다 분 소 화율이 유의적으로 높은 것으로 나타났다(I< 0.05). 결론적으로, 자돈에 있어서 중국산 옥수 수를 익스트루젼 가공 처리하면 성장 및 건물 과 가소화 에너지 소화율을 향상시킬 수 있으 며, 비육돈에 있어서는 건물과 질소의 분 소화 율을 향상시킬 수 있는 것으로 사료된다.

\section{$\mathrm{VI}$ 인 용 문 헌}

1. Amstrong, D. G. and Mitchell, H. H. 1955. Protein nutrition and the utilization of dietary protein at different levels of intake by growing swine. J. Anim. Sci. 14:49.

2. AOAC. 1995. Official Method of Analysis. 16th ed. Association of Official Analytical Chemists, Washington, D. C., USA.

3. Duncan, D. B. 1955. Multiple range and multiple F tests. Biometrics 11:1.

4. Herkelman, K. L., Rodhouse, S. L., Veum, T. L. and Ellersieck, M. R. 1990. Effect of extrusion on the ileal and fecal digestibilities of lysine in yellow corn in diets for young pigs. J. Anim. Sci. 68:24142424.

5. Hongtrakul, K., Goodband, R. D., Behnke, K. C., Nelssen, J. L., Tokach, M. D., Bergstrom, J. R., Nessmith, Jr. W. B. and Kim, I. H. 1998. The effects of extrusion processing of carbohydrate sources on weanling pig performance. J. Anim. Sci. 76:30343042 .

6. National Research Council. 1998. Nutrient Requirements of Swine. 10th ed. National Academy Press, Washington, D. C., USA.

7. SAS. 1996. SAS user's guide. Release 6.12 ed. SA S Institute. Inc., Cary, NC.

8. Serrano, S. 1997. The extrusion-cooking process in animal feeding. In : Feed Manufacturing in Southern Europe : New Challenges. Morand-Fehr, P(ed.). CHIEAM-IAMZ. pp 107-114.

9. Swell, R. F. and Maxwell, C. V. 1966. Effects of various sources of carbohydrates in the diet of early weaned pigs. J. Anim. Sci. 25:796-799.

10. U.S. Grains Council. 2001. U. S. Grains Council VEG Exporter Manual. http://www.grains.org.

11. U.S. Grains Council. 2002. Grain: World Markets and Trade. http://www.grains.org.

(접수일자 : 2003. 7. 21. / 채택일자 : 2003. 12. 5.) 